\title{
Střípky z historie katetrizačních vyšetření v Hradci Králové
}

\author{
Vladimír Rozsíval \\ Kardiologické centrum AGEL, a.s., Pardubice
}

O možnosti srdečních operací se začali chirurgové zajímat již v padesátých letech minulého století. Vyvíjel se mimotělní oběh, stoupaly znalosti o srdečních chorobách a kromě fyzikálního vyšetření byly vyvíjeny katetrizační techniky v návaznosti na počáteční zákroky W. Forssmanna. Po katetrizaci pravostranné to byla také retrográdní levostranná, měření srdečního výdeje, tlaků a kvantifikace zkratových i chlopňových vad. Katétry byly zaváděny za skiaskopické kontroly, nejdřive chirurgickou preparací, posléze podle S. Seldingera i punkčně. Po zavedení transseptální punkce J. Rossem se zpřístupnila též cesta do levé síně, která byla do té doby (1959) získávána i poněkud bizarními způsoby, jako např. transbronchiální punkcí. I když chirurg potřeboval přesné informace o tom, co a jak má operovat, někteř́ slavní kardiochirurgové neměli k radiologům a kardiologům důvěru. Ǩíkali, že otevřou srdce a operují, co vidí. Tato cesta však byla slepá. Operativa srdce byla v tehdejší době v Československu prováděna na několika pracovištích v Praze, v Hradci Králové, Brně a Bratislavě.

Historie počátků katetrizace v Hradci Králové, nutno podotknout, že se jedná o dobu před zavedením ultrazvukových vyšetření srdce, je úzce spjata s kardiologem doc. J. Endrysem, který priš̌el do Hradce Králové z Olomouce v roce 1957, a prof. L. Steinhartem (později přednosta radiologické kliniky). V této době bylo zavedeno fotometrování (barevná diluce) k měření minutového srdečního výdeje, ke kvantifikaci regurgitací, detekci a kvantifikaci zkratových vad. Nedlouho po Rossově zprávách o transseptální punkci byla tato provedena i v Hradci Králové. Zajímavostí je, že jehly k transseptální punkci si vyráběl prof. J. Endrys doma, a to tak, že s L. Steinhartem sehnali trubičky a následně sletovali hroty a konce. Později tuto modifikaci dlouhé transseptální jehly vyráběla firma Cook. Na rozdíl od Rosse používali kontrastní materiál katétrů a jako první na světě aplikovali kontrastní látku do levé síně (cca 1960). Měření tlaku ve všech srdečních oddílech bylo samozřejmostí. Vyprávění doc. J. Endryse mi trochu připomnělo A. Gruentziga, který si „pekl“ první balonkové katétry doma v troubě. Následně byl doc. J. Endrys osloven společností Petrof, proslulou po celém světě výrobou klavírů, a výsledkem byla kromě výroby strun ke klavírům a pianům také výroba vodičů ke katetrizaci, a to o dva roky dríve nežn.p. Dita. V 60. letech 20. století se tedy "vesele“ katetrizovalo kolem pěti nemocných za týden, později i více. Koronarografie sice ještě nebyla v popředí zájmu kardiologů či kardiochirurgů, nicméně již tehdy byl protokol katetrizace celkem obsáhlý. Byly v něm mimo jiné simultánně měřené tlaky ve všech srdečních oddílech (před a za chlopní), změřeny tlakové gradienty, vypočitán minutový srdeční výdej, regurgitační frakce, kvantifikace zkratových vad, dopočítána plocha chlopenních ústí a vypočitána plicní arteriální rezistence. Laboratoř dbala o přesné měření tlaku a průtoků. Rozdíl měření byl tolerován do 5\%. Až do druhé poloviny 80 . let byly v Hradci Králové katetrizovány i děti. Kromě doc. J. Endryse katetrizoval i M. Petrle, dětské pacienty doc. M. Frank, J. Roessler, dále pak prof. Z. Bělobrádek, doc. A. Hamet a J. Šístek. Později je následovali také J. Balatka, M. Křivková, I. Jurin, J. Baštecký.

Doc. J. Endrys byl velkým učitelem katetrizace. V Hradci Králové školil řadu českých lékařŭ, např. doc. K. Hlaváčka, M. Rubáčka, prof. R. Čerbáka, ale své zkušenosti rozdával i v zahraničí. Dle jeho údajů
Obr. 1. Doc.J. Endrys prì rozboru nálezůnemocného

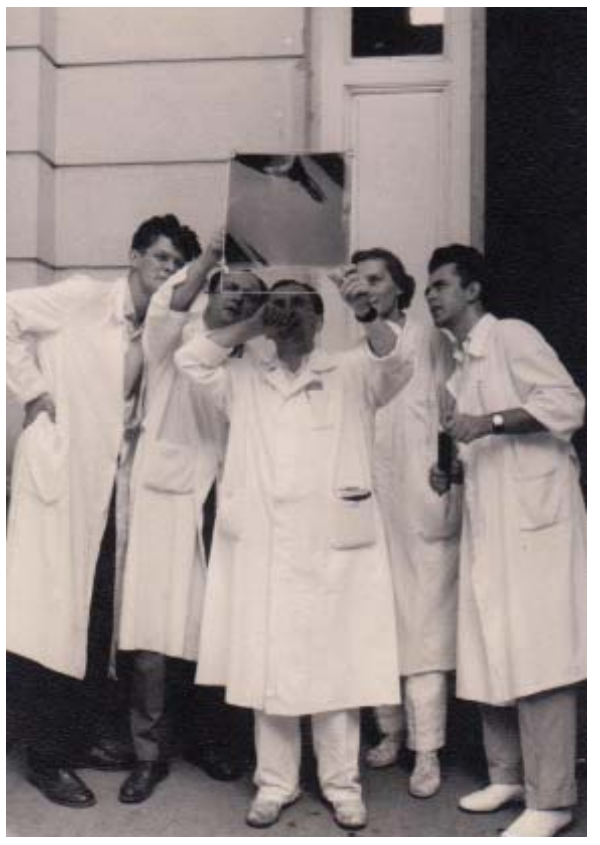

přednášel či katetrizoval ve většině států Evropy, např. v Německu, Mad’arsku, Polsku, Anglii, ale i v exotickém Egyptě. V roce 1969 založil v Kuvajtu katetrizační pracoviště a řadu let tam i pracoval. Kromě samotných katetrizací patřily mezi jeho priority také uzávěry AV piššělí v plicích odpoutatel-

KORESPONDENČNÍ ADRESA AUTORA:

MUDr. Vladimír Rozsíval, CSc., vladimir.rozsival@kca.agel.cz

Kardiologické centrum AGEL, a. S., Kyjevská 44, 53203 Pardubice 
Obr. 2. Doc. J. Endrys prí demonstraci modelu transseptálnípunkce

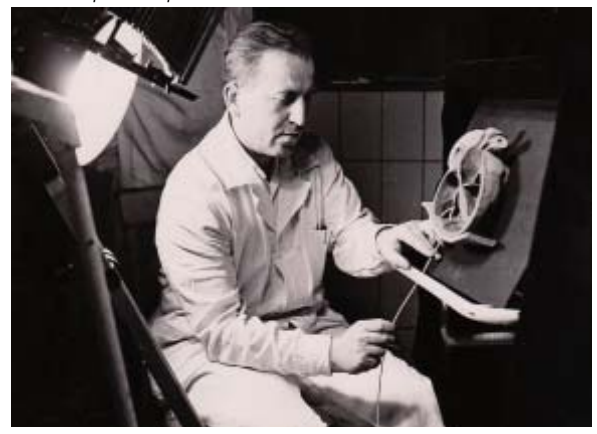

Obr. 3. Záběr z katetrizace v šedesátých letech

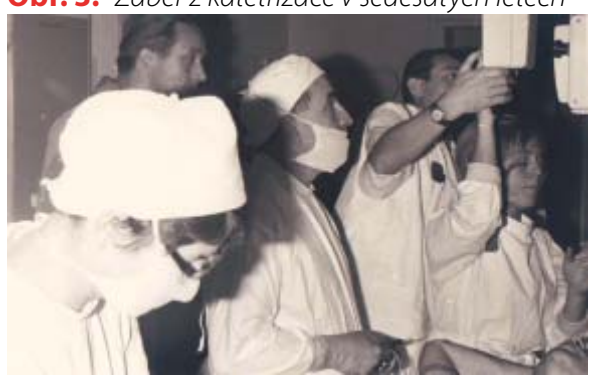

Obr. 4. Jiř́ Endrys v době největšího rozmachu katetrizací

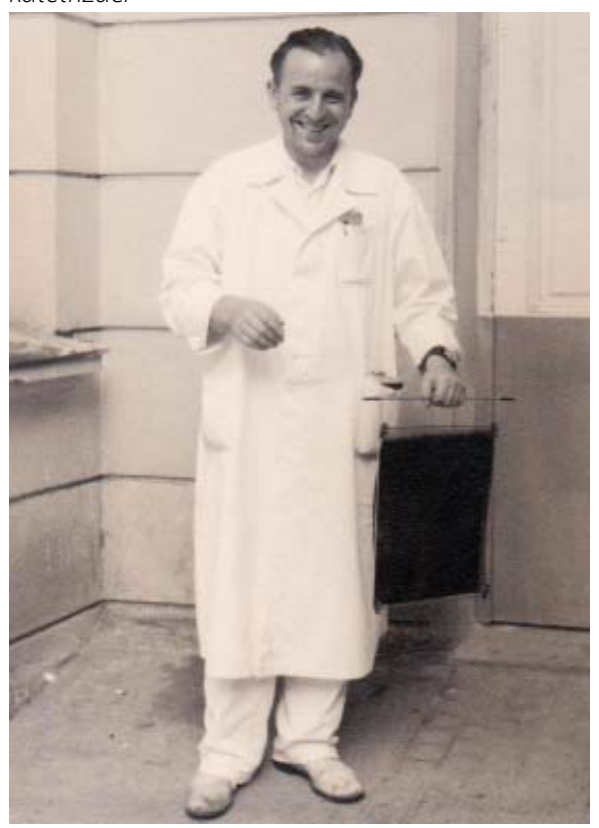

ným latexovým balonem, katetrizace novorozenců, punkce a. radialis před operací apod. Na svém kontě má i další světový unikát, a to vynález zařizení ke kvantifikaci zkratů na základě termodiluce.

Mezi další legendy hradecké katetrizace patř́ i dosud nezmíněný prof. J. Kvasnička, který do Hradce Králové nastoupil v roce 1960, kdy byl ještě katetrizační program centralizován na staré chirurgické klinice. Prof. Kvasnička sbíral zkušenosti mimo jiné např. v Anglii, kde v roce 1966, kdy nebyly ještě koronarografie rutinně prováděny, transseptálně katetrizoval. Mezi přední zájmy prof. Kvasničky v té době patřila kontraktilida myokardu. Další dlouho-

Obr. 5. Záběry z prednášky o katetrizaci

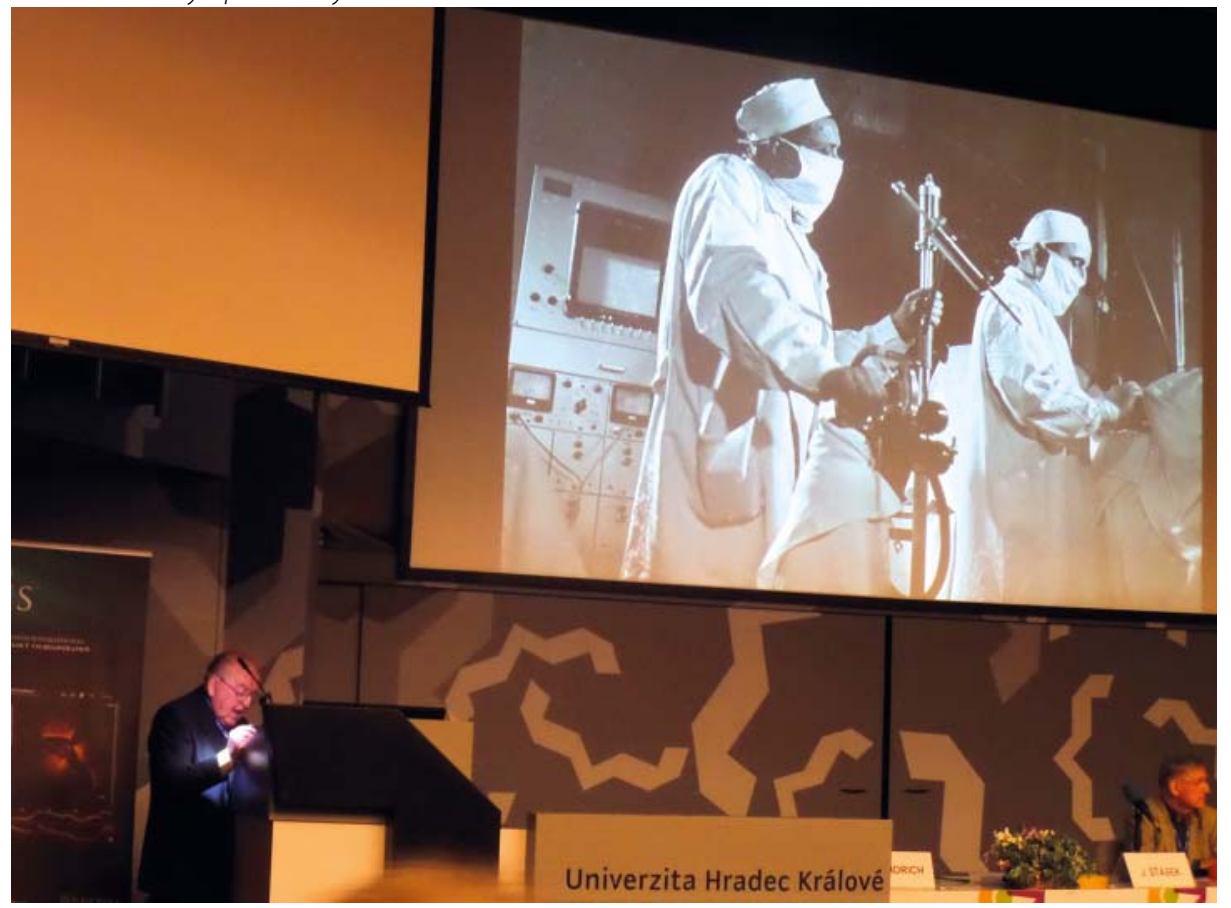

dobou pracovní stáž absolvoval prof. Kvasnička ve Švédsku v roce 1971, ale ani tam zatím nebyly koronarografie v popředí zájmu katetrizujících. Akutní koronární péče se začala postupně vyvíjet koncem šedesátých let. V Hradci Králové byl v časopisu Mladý Svět v roce 1968 publikován první hradecký nemocný, který prežil fibrilaci komor u akutního srdečního infarktu. V souvislosti s tímto prípadem se traduje, že prof. Kvasnička strávil s pacientem celou noc na vedlejším lůžku. V této době zde začala působit další významná osobnost hradecké kardiochirurgie, a to MUDr. J. Reček, který se začal blíže zajímat o možnost chirurgické revaskularizace.

Po návratu ze Švédska prof. Kvasnička spolu s préednostou patologické fyziologie na LF v Hradci Králové L. Vokrouhlickým v roce 1972 zahájili diagnostický program pro nemocné s ICHS. Tento program trval celý týden, začal v pondělí laboratorním vyšetřením, zátěžovým testem (bicyklová ergometrie), UZ vyšetřením na v té době jediném ultrazvukovém př́stroji na katedře fyziologie, provedením spirometrie, fonografie a časových intervalů srdečního svalu. Později byly vyšetřovány také katecholaminy v sinus coronarius prì rychlé komorové stimulaci. Ve čtvrtek následovalo provedení koronarografie, a to výlučně doc. A. Hlavou. Za týden bylo takto koronarografováno pět nemocných, z nichž byl vybrán jeden k aortokoronárnímu bypassu. Tento byl na kardiochirurgii operován vždy ve středu. Rentgenologové ještě v 80. letech nechtěli prípustit, aby koronarografii prováděli i katetrizující kardiologové. Ti začali postupně koronarografovat až v druhé polovině 80. let u vad, později pak celý program koronarografií přešel na kardiologická pracoviště, která koronarografují ve velkých počtech približně od počátku 90. let. Hradečtí rentgenologové nové generace, hlavně prof. A. Krajina, byli rozumní a rozvíjeli řadu vynikajících metod (mozkové intervence, TIPS, uzavírání a otevírání cév v celém těle) a prenechali péči o malé tři cévy na srdci kardiologům. A tak od první poloviny 80. let začali v Hradci Králové katetrizovat a koronarografovat lékaři nové generace: D. Černohorský, V. Rozsíval, doc. J. Štásek, později prof. P. Červinka, A. Herman, I. Varvařovský, M. Brtko, P. Polanský, J. Bis, J. Dušek a rada dalších.

V souvislosti s vývojem katetrizačních vyšetření v Hradci Králové je nutné věnovat pozornost také rtg vybavení, katétrům a počtům nemocných. Od roku 1976 do roku 1985 byly katetrizace ještě prováděny v suterénu starých chirurgických klinik. Pracovali zde lékaři z I. interny (2 dny), z II. interny (2 dny) a rentgenologové. U stolu byl katetrizační lékař a současně katetrizační sestra, která připravovala nemocného, rouškovala, pripravila stolek s nástroji apod., a v neposlední řadě také rentgenový laborant. Další sestra zajištovala podání lékủ a dohlížela na nemocného. V centrále pracovala sestra (laborantka), která registrovala tlaky, zapisovala diluční křivky a sledovala EKG. V laboratoři byl pak prítomen ještě bioinženýr. Rentgen byl fixní, snímač se pohyboval pouze nahoru a dolů. Nebylo tedy možné provádět angulované projekce zdola 


\section{INTERVENČNÍ A AKUTNÍ KARDIOLOGIE}

STŘ́PKY Z HISTORIE KATETRIZZČNIÍCH VYŠETŘENIV HRADCI KRÁLOVÉ

Obr. 6. Hlavním operatérem srdce byl v šedesátých a sedmdesátých letech prof. J. Procházka - zde obklopenýlékarí prí prípravě operace; sedicí od leva - prof. L. Steinhart, prof. J. Procházka, dr. Řehoř, stojicí odleva: druhý prof. Z. Bělobrádek, dále prof. J. Kvasnička, doc. Endrys a dr. Jurin

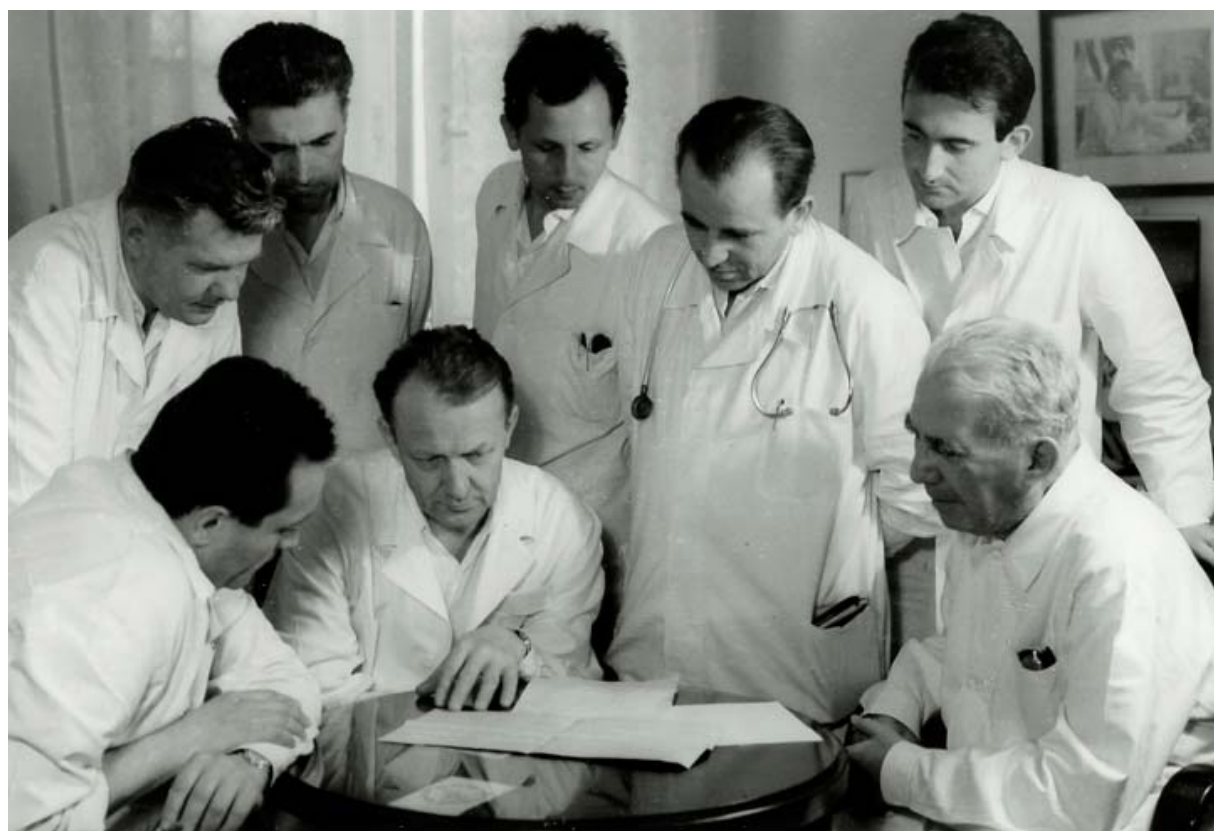

a shora. Nemocný byl připoután do „kolébky“, která se otáčela podél dlouhé osy. Jediná angulovaná projekce byla LAO shora, kdy byl nemocný odpoután, posazen do polosedu a zezadu podpírán. Někdy bylo obtižné najít napríklad odstupovou stenózu RIA, RC z kmene levé věnčité tepny, protože některé cévy se překrývaly. Také nebylo možné skiaskopický záznam opakovat na zpětné kličce. Vstřik byl bedlivě sledován a zmizel. Záznam několika nemocných se prováděl na kotouč filmu a byl definitivně zhodnocen až koncem týdne po jeho vyvolání. Zvláště obtí̌né bylo v tomto režimu až do roku 1994 provádění koronárních intervencí. $\checkmark$ roce 1985 byla sice laboratoř přestěhována do nové budovy chirurgických klinik, ale moderní prístroj s možností nekonečného opakování záběrư a s pohyblivých "C" ramenem byl instalován až v únoru 1994. Čekací doba na invazivní vyšetření byla tehdy jeden rok i déle.

Co se týče cévního prístupu, ten byl prakticky výhradně a. a v. femoralis. Punkce byly prováděny i přes aortofemorální bypassy. Zcela výjimečně byl zvolen axilární prístup. Rentgenologové prováděli i translumbální prístup, který pro vyšetření srdce nebyl vhodný. Transradiální, poprípadě transulnární či brachiální prístup byl zaveden až začátkem 21 . stolení. Je s podivem, že v 80 . letech nebyly rutinně používány zavaděče (sheaty) do tepen, presto, že byly použivány $8 \mathrm{~F}$ katétry, byla potřebná postupná dilatace vpichu. Lze si představit pozdější dlouhé držení místa vpichu k zabezpečení zastavení krvácení, po kterém následovala bandáž a dlouhý klid na lưžku, a to deset a více hodin.

Katétry byly, na rozdíl od dnešní situace, nedostatkové, a proto byly sterilizovány a používány opakovaně, než byly vyřazeny pro nemožnost ovládání. Později se zavedlo použití "3x a dost". Vlivem opakovaného použití docházelo k prodloužení doby výkonu, protože manipulace s katétrem, který byl v oběhu po několikáté, byla obtížnější. Opakované použití katétru určeného na jedno použití je dnes nejenže zcela nemyslitelné, ale vzhledem k současné legislativě navíc i trestným činem. Nicméně dle pamětí K. Amplatze se i v USA svého času katétry resterilizovaly. Některé si dokonce lékaři i sami vyráběli, nebo upravovali prímo na sále horkým vzduchem a následným zchlazením. K. Amplatz dokonce popisuje, že některý z katétrů měl oblíbenou přezdívku, se kterou si ho operatér žádal. I v Hradci Králové bylo vyrábění některých katétrů, nikoli však koronárních, běžné. Používaly se hadičky různých průměrů a barev, které se dovážely především z bývalé NDR na kotoučích. Na konci roku pak jednotlivé BSP (brigády socialistické práce) vykazovaly úspory, které získaly proti kupovaným originálním katétrům. K tomuto období v 80. letech se váže i tragikomická príhoda, kdy byla koronarografována manželka vysoce postaveného komunistického funkcionáre ostře sledována vedením nemocnice. Operatér dostal nepoužité koronární katétry, jejichž problém byl, že měly prošlou expiraci, protože zůstávaly v rámci šetření ve skříni. Tyto katétry neměly ještě bezpečnostní jádro a během vyšetření došlo k rozlomení jednoho z nich na několik částí, které byly poté několik hodin odstraňovány "lasíčky“ z různých částí oběhu.

Určitým přelomem byl rok 1990, kdy byly započaty koronární intervence. Již v roce 1988 a 1989 bylo provedeno celkem osm balonkových angioplastik (A. Hlava, A. Krajina) s asistencí nervózních kardiologů. Od roku 1990 byl ale tento výkon prováděn již pouze kardiology (V. Rozsíval, J. Štásek). V počátcích byly rovněž balonky a vodiče resterilizovány, nicméně v dalších letech se situace zlepšila a navíc legislativa již resterilizace nepovolovala. Práce s novým materiálem na jedno použití byla radostí, protože ovladatelnost katétrů, vodičů a zavedení balonků bylo podstatně snazší. Velkým mezníkem byl rok 1994 nejen díky implantaci prvních stentů, ale rovněž díky novému přistroji, který umožňoval opakovaný obraz, angulovanou projekci a obraz s lepší rozlišitelností. V roce 1994 byla také v Hradci Králové provedena první implantace stentu (V. Rozsíval).

Postupujícím časem následovaly další speciální výkony, jako kontrapulzace, uzávěry mezisíňové přepážky (PFO, DSS), uzávěry ouška, ablace septálních tepen, balonkové dilatace mitrální a aortální stenózy, náhrady aortální a mitrální chlopně katetrizačně. Objevily se nové intervenční metody, které jsou uplatňovány u složitých komplexních kalcifikovaných bifurkačních lézí. Zlepšila se diagnostika - intrakoronární ultrazvuk, OCT, apod. V neposlední řadě je nutno zmínit, že toto vše vedlo ke zlepšení komfortu pacienta. Některé výkony je již možno provádět ambulantně, v režimu stacionáře. Velmi se také rozširíily indikace i na klinické situace a složité nálezy, které by dřive nebylo možné akceptovat.

Ale to už není historie...

Za poskytnutí cenných vzpomínek děkuji doc. J. Endrysovi a prof. J. Kvasničkovi, za zaslání historických snímků děkuji dr. L. Harrerové.

MUDr. Vladimír Rozsíval, CSC. 